This is the accepted manuscript of an article forthcoming in Enterprise \& Society.

Please cite the published version.

\title{
Inside and Outside the London Stock Exchange: \\ Stockbrokers and Speculation in Late Victorian Britain
}

James Taylor, Lancaster University

Introduction

When it comes to social and cultural histories of capitalism, we know a lot more about how people spent their money than how they invested it. ${ }^{1}$ The institutions and practices of nineteenth-century consumer society - the department stores, the development of the advertising industry, the democratization of luxury - have been thoroughly mapped out by scholars since the 1990s. ${ }^{2}$ Yet while spending and investing are easily imagined as opposites - one representing the indulgence of gratification, the other its deferral - a culture of investment was developing in late Victorian Britain which appealed to similar desires and emotions as were played upon by consumer capitalism. In the same way that advertisers, manufacturers, and retailers were creating mass markets for consumer goods, so other actors were using innovative methods to appeal to small investors, widening participation in financial markets.

This culture has been obscured by a focus on the London Stock Exchange. Though becoming the center not only of the national but also the international securities market, the London Stock Exchange was distinguished by its "neglect of the small investor." Its stockbrokers preferred larger clients: they were more likely to pay their debts, required less attention, and were more lucrative than smaller clients, since the broker's main income 
derived from a percentage commission on each transaction. Thus, they did not advertise indeed the rules of the London Stock Exchange forbade it - acquiring new business through personal introductions from existing clients. Provincial stock exchanges tended to follow this lead, also imposing advertising bans on its members, limiting their ability to reach new investors. This conservatism imposed limits on the "democratization" of stock ownership. ${ }^{4}$ Yet, if we look beyond the official market, we glimpse a different picture. The enclosure of the London Stock Exchange at the beginning of the nineteenth century created a distinction between "inside" and "outside" stockbrokers. Anyone unwilling or unable to meet the Stock Exchange's membership requirements was free to do business outside. ${ }^{5}$ The activities of these outsiders occasionally surface in histories of the London Stock Exchange, particularly at moments of conflict between members and non-members. By necessity, however, they feature as bit-players, peripheral to the main story of the growth of the official exchanges. ${ }^{6}$ They have occasionally attracted more sustained attention. In a pioneering article, David Itzkowitz shows how in the late Victorian period outside brokers borrowed methods from professional bookmakers, using "aggressive advertising” and sensational appeals to introduce speculation to a wider audience. ${ }^{7}$ Dilwyn Porter provides an equally valuable survey of the varied ways in which outsiders targeted inexperienced investors from the 1880 s to the start of the Second World War. ${ }^{8}$ Important though this work is, it conceptualizes outside brokers as disreputable and dishonest adjuncts to the "real" market for stocks and shares, whose main - if unintentional - impact was to legitimize the established exchanges. Porter, for example, though recognizing the diversity of outside firms and noting that some behaved honorably, focuses on the fraudulent among their number, the "parasitic enterprises" and "fringe operators" that preyed upon "the greedy, the stupid and the unworldly."9 
Alternative approaches are possible, however. Kieran Heinemann has recently made a persuasive case for focusing on "the fringes of financial markets" as a "legitimate and vibrant entry point for investment newcomers." He explores this theme in relation to what he calls the "grey market for stocks and shares" after the First World War, in which outside brokers were prominent. ${ }^{10}$ His analysis is complemented by an article by Matthew Hollow in this journal which documents the "share-pushing" activities of outsiders in the interwar period. ${ }^{11}$ Though sharing Porter's focus on fraud, he uses the activities of outsiders to map the financial advice landscape and explore how investors, particularly new investors, navigated the market. Looking more closely at market outsiders can indeed give new perspectives on how participation in the market was extended, but in this article, I suggest that the late Victorian years provide an even better vantage point from which to observe this process. This was the period that first saw the outside broker rise to prominence, with a raft of outsiders challenging the hegemony of established operators. Their continuing success into the interwar period rested largely on a refinement of practices pioneered from the late 1870 s.

Itzkowitz compares outside brokers to bookmakers, but an alternative analogy can be found in the market for consumer goods. Borrowing techniques from entrepreneurial contemporaries like William Lever and Thomas Barratt, outside brokers developed a mass market, not for soap, but for speculation. ${ }^{12}$ Though outnumbered by insiders, they leveraged their advantages to transform the market for stocks and shares. Their blanket advertising brought the stock market to the attention of new ranks of potential investors, making it a subject of curiosity. Their active branching policy moved investment out of the City of London and made it more accessible to larger numbers of people. Their information and advice services promised to demystify the markets for the masses. Outside brokers became high-profile figures whose visibility made them the public face of the stock market, despite having no official connection with the London Stock Exchange. Thus, despite their persistent 
association with fraudulent practices, they became hugely influential intermediaries who shaped many people's understanding of and engagement with the market.

As others have observed, researching outside brokers poses problems. ${ }^{13}$ Relatively few collections of stockbrokers' papers survive in the archives, and those that exist are of inside rather than outside brokers. But a detailed picture of their activities can be pieced together from nineteenth-century newspapers and periodicals, which contain not only their advertisements, but also news stories, editorial comment, advice columns, readers' letters, and court reports involving outside brokers. Yet these materials contain pitfalls: unpicking the financial agendas influencing newspaper coverage can be difficult; legal reports, though furnishing some of the richest material on outside brokers, may not be entirely representative of their business practices. The research strategy has been to read as widely as possible across the newspaper and periodical press, encompassing the diversity of titles which reported on or carried advertisements for outside brokers, and assessing both critical and sympathetic comment. ${ }^{14}$ Other sources have been used: although brokers' circulars do not survive in large quantities, their investment manuals do, and these give important insights into their appeal to investors. ${ }^{15}$ Finally, the records of the London Stock Exchange and the Exchange Telegraph Company contain many useful references to the activities of outsiders.

This article uses these sources to re-evaluate the significance of outside brokers, exploring their methods and the reasons for their success. The first section briefly sketches the growth of the outsiders' business and the resulting backlash from the later 1880s. The rest of the article attempts to explain why, despite a moral panic about these outsiders, they were able to thrive for so long. The second section surveys the various methods of communication used by the brokers, showing how they harnessed the power of print to reach wide constituencies of potential investors. The third focuses on how outsiders helped to recalibrate attitudes, blurring the boundaries between investment, speculation, and gambling, recasting 
playing the stock market as an exciting but safe and legitimate activity. The fourth explores why these methods inspired trust, and the fifth assesses the complex relationship between the inside and outside markets. The conclusion suggests the wider implications of studying financial "fringes" for understanding capitalism. Histories of the stock market tend to draw on official sources of publicly quoted securities and their holders. This work has provided us with a rich and quantitatively precise view of the growth of the stock market, tracing who invested and what they invested in. ${ }^{16}$ But it does not provide the whole picture, and this article is an attempt to bring into view a hidden but important side of this market.

The Rise of the Outsiders

The market for stocks and shares was originally an open market, conducted in a variety of locations, including the Royal Exchange, the Rotunda of the Bank of England, and, most famously, the coffee houses of the City of London. Though the City Corporation possessed powers to license stockbrokers, the trade was in fact carried on by a mix of "sworn" and "unsworn" brokers. ${ }^{17}$ Moves towards creating a closed market, culminating in the establishment of a members-only Stock Exchange in 1801, did not create a monopoly. ${ }^{18}$ Trade continued outside "the House," with a host of brokers, dealers, and auctioneers making up a diverse financial market. And when stock exchanges began to form in the larger towns and cities from the 1830 s, the inside-outside dynamic was replicated across the country. ${ }^{19}$ Initially attracting little attention, outsiders first gained a higher profile during the "railway mania" of the 1840 s. Going by many names - "stags, outside men, third class train, or stand ups" - they specialized in buying and selling letters of allotment for railway shares, a trade which took place in the alley outside the Stock Exchange. They were considered “disreputable dealers", and their main occupation was "plundering" small tradesmen and 
"other unfortunate individuals." ${ }^{20}$ But outsiders were mainly known for their association with the market for mining shares. Domestic mines had been neglected by the London Stock Exchange because of their distance from the capital, their unpredictability, and the difficulty of getting reliable information on them, allowing the field to be dominated by outside dealers. ${ }^{21}$ The tendency of these dealers also to be involved in company promotion and management created conflicts of interest which gave them a dubious reputation. Accused of manipulating share prices, misrepresenting the prospects of mining ventures, and seeking to offload overpriced shares onto unwary investors, one such dealer admitted in 1853 that the public saw them as "little better than card swindlers."22

But from the 1870s, a growing number of ambitious outside brokers were shedding their association with the mining share market, recasting themselves as general stock and share brokers. They were encouraged by a range of factors that were beginning to make investment in stocks and shares a viable proposition for greater numbers, including the wider availability of investments with limited liability, lower share denominations, rising incomes for growing numbers of white-collar workers, and reforms to married women's property rights. ${ }^{23}$ Another factor was the arrival of the new technology of the "tape." Prices of stocks were telegraphed from the London Stock Exchange to receiving machines in brokerages across London which printed them on a spool of paper. The "ticker," as it was sometimes known on account of the sound it made when in action, had been adopted by the New York Stock Exchange in December 1867, and started operation in London five years later, following the formation of the Exchange Telegraph Company. ${ }^{24}$

Both inside and outside brokers subscribed to the tape service, but only outsiders realized its transformative potential, often taking on multiple machines, making them freely available to their clients, and making this a central element of their sales pitch. The continuous supply of prices represented a significant step towards the mechanization of stock 
dealing, increasing the speed and reliability of transactions. And it provided the raw materials for speculation. Customers would select which stock they wanted to operate in, and whether they wanted to speculate for a rise (a "bull”) or for a fall (a "bear"). They then deposited "cover," which could be as little as one per cent of the value of the stock, together with commission of $1 / 16^{\text {th }}(6.25 \%)$. This meant that just $£ 5$ 6s $3 d^{\text {" commanded" }} £ 500$ stock, in the language of the brokers, while those with $£ 215$ s to risk could "command" $£ 2,000$ stock. If a client was "bulling" a stock, and the tape price went up by one percent, they could close the transaction, pocketing the difference and their cover - or keep it open hoping for even bigger profits. If the stock went down by one per cent, their cover "ran off" and the transaction ended. By the end of 1885, the Exchange Telegraph Company was supplying 140 tape machines to non-members. ${ }^{25}$

But the proliferation of this type of speculation generated anxieties which threatened to overtake the outside brokers. By the mid-1880s, with close to 200 outside firms doing business in the capital, outside brokers had become a frequent subject of hostile comment. ${ }^{26}$ The press had long been a key reputation broker in the financial markets, and there were no shortage of voices willing to challenge the rise of the outside brokers. ${ }^{27}$ For critics, speculation on the cover system was gambling, pure and simple. Those who did it were not actually investing in the stock market, they pointed out, but gambling on price movements. Moreover, it was a rigged gamble. Whereas inside brokers were the agents of their clients, outside brokers were effectively principals in their transactions with customers, much like bookmakers and punters. In other words, when their customers lost - when the cover ran off - they won. Therefore, they had every incentive to make sure this happened. Those who risked their money in this way "lose their money, probably, nineteen times out of twenty." 28 When growing pressure of competition between outsiders led several of them to begin offering commission-free dealing, critics presented this as a dangerous deception designed to 
tempt the unwary with a veneer of fake philanthropy. ${ }^{29}$ And whilst dealing with an inside broker meant having recourse to the London Stock Exchange's Committee for General Purposes in the event of a dispute, those dealing with outsiders had no such protections. Outside brokerages were increasingly stigmatized as "bucket shops," a term originating in the US for low-class drinking houses, but which had come to be applied to brokerages competing with the Chicago Board of Trade, and which quickly made its way over the Atlantic. ${ }^{30}$ Newspapers warned their readers against the bucket shop menace. ${ }^{31}$ By the early 1890 s, disquiet had developed into a full-blown moral panic with calls for legislative intervention. In 1893, the recently formed National Anti-Gambling League began working with former Attorney General, Sir Richard Webster, to draw up a bill to define outside brokerages as common gaming houses and therefore illegal under the terms of the 1845 Gaming Act. ${ }^{32}$ Though this came to nothing, outside brokers who misappropriated their clients' money could be criminally prosecuted, and judges in both criminal and civil actions often commented in scathing terms about the business practices of the outsiders. ${ }^{33}$

Increasingly worried about the competition they posed, as well as possible reputational damage, the London Stock Exchange took steps against the outsiders. In 1885 the Committee for General Purposes tried to block the supply of tape prices which sustained the outsiders' business by expelling the Exchange Telegraph Company from the floor of the House. This proved ineffective, however, as the company simply set up shop just outside the Exchange where it was able to continue sourcing prices from members as they came and went. After eighteen months, its operatives were readmitted to the House. But anxieties about competition persisted, and in 1893 the Committee tried a different strategy, requiring the Exchange Telegraph Company to stop supplying prices to outside brokers. ${ }^{34}$ But cutting off the outsiders did not curb them for long, and they continued to flourish into the 1930s. It was only legislative interference that eventually ended their operations. ${ }^{35}$ 
How outside brokers were able to win and maintain trust in the face of copious press criticism, the hostility of judges, and the opposition of the London Stock Exchange requires some explanation. For contemporaries, the irrationality of the public, particularly small investors, was to blame. The Times was representative when in an 1898 editorial it wondered at the persistence of "human credulity" in the modern age. Seeing similarities between outside brokers and patent medicine vendors, the fact both were able to get rich by promising "short cuts to health and wealth" was proof of the enduring "gullibility" of the public, resistant to experience and reasoning alike. ${ }^{36}$ Even if not sharing the condescension of such judgements, historians have perhaps not done enough to challenge their underlying assumptions, leaving us with a somewhat skewed perspective. Conceiving of outsiders as essentially fraudulent and their victims as fools creates an overly-simplistic dichotomy between honest insiders and crooked outsiders which whitewashes official exchanges, obscuring some of their own problematic practices. It also fails to take into account important characteristics of the information landscape in which investors operated. And, by focusing on character traits rather than states, it pays insufficient attention to important drivers of investment behavior. As scholars are increasingly insisting, framing discussions of behavior in terms of "rationality" and "irrationality" is somewhat limiting if we want to fully understand the contexts in which decisions were made. ${ }^{37}$

The Power of Print

Inside brokers had an effective system for bringing in new business. They employed hosts of agents - variously called "touts," "runners," "remisiers," and most frequently "halfcommission men" - to win them new clients, sharing the commission with them. Wellconnected young men would haunt the West End clubs, "where they 'preyed' on relatives, 
old school friends, and the like for business." ${ }^{38}$ Likewise, brokers split commission with banks, accountants, lawyers, and members of the provincial stock exchanges. Thus, investors could do business with an inside broker without having any direct contact with him. However extensive this system was - and one Edwardian journalist estimated that there were around 20,000 such agents in operation - it was not sufficient to monopolize the stock and share business for the insiders. ${ }^{39}$ Relying upon personal, face-to-face relations rather than exploiting the growing power of print, there were natural limits to its reach. Those who did not encounter an agent for an inside broker were increasingly likely to discover one of the growing ranks of outside brokers who were making themselves visible through modern advertising methods.

Spurred on by the repeal of the "taxes on knowledge" between 1853 and 1861, the second half of the nineteenth century witnessed "an exponential growth in the number of places where news was read and bought." 40 As well seeing the establishment of new titles, newspapers were now published more often, with a big increase in dailies, and they were getting cheaper, with penny papers becoming more available from the $1860 \mathrm{~s} .{ }^{41}$ The significant increases in circulation which lower prices brought about also enabled newspapers to grow in size, offering more pages for the same low price. Advertising, always crucial to the economics of the press, became even more so in an age of intensifying competition and shrinking margins on sales. New titles scrabbled to win advertisers, who were thus able to leverage generous terms. ${ }^{42}$

Though they had long used the press, outside brokers capitalized on these changes to begin advertising more consistently and more extensively from the $1850 \mathrm{~s}$. Often bunched together in the advertising columns, their notices represented in effect an "investors' corner" catching the eye of anyone with money to place. ${ }^{43}$ Advertising brokers were also paying more attention to sales techniques, using eye-catching headlines to attract attention. Thus, a typical 
advertising column of The Times in May 1860 featured four successive notices, headlined “SHARES WANTED," "PROFITABLE INVESTMENT," "MINE SHARES for SALE,” and “SAFE INVESTMENT” respectively. ${ }^{44}$ By the 1880s, brokers' advertisements had become more prominent still. Firms like W. Gutteridge and Co., John Shaw, and the Universal Stock Exchange were emulating the more ambitious consumer goods firms by taking whole columns, then double columns, and eventually even full-page adverts. ${ }^{45}$ Their advertisements colonized every type of newspaper available: the London and provincial press, niche publications such as the Civil Service Gazette and the Court Journal, and, of course, the burgeoning specialist financial press. ${ }^{46}$ In some cases, they even began publishing their own newspapers. ${ }^{47}$ Advertising became a major element of these firms' budgets, with George Gregory and Co.'s annual ad spend in the 1890s lying in the region of $£ 30,000 .{ }^{48}$ While not quite matching the most prolific advertisers such as Beecham's, who by this point were spending around $£ 100,000$ annually, publicity was clearly as integral to their success as it was to manufacturers of pills and soaps, allowing them to reach a national market. ${ }^{49}$

Newspapers were just one aspect of the nineteenth-century "explosion of print." Circulars had long been a means for brokers to communicate with their clients, though print runs were modest, and the circulars tended to be little more than price lists. ${ }^{51}$ However, cheaper paper, advances in printing technology, and postal reforms rendered circulars a much more effective mass-marketing tool. ${ }^{52}$ Circulars made up a sizeable part of the astonishing $441 \mathrm{~m}$ book packets which were being sent annually by the end of the $1880 \mathrm{~s} .{ }^{53}$ Though inside brokers were permitted to circularize their clients, they were not allowed to send their circulars to strangers, to prevent poaching, a rule which was rigorously enforced by the Stock Exchange's Committee for General Purposes. ${ }^{54}$ They were therefore prevented from employing the services of the growing number of businesses harvesting the names and addresses of shareholders from public registers to sell to firms who wanted to reach large 
numbers of possible investors. ${ }^{55}$ But outside brokers could and did, notching up huge print runs for their circulars, which evolved beyond simple price lists into more sophisticated market reports or tip-sheets. One outside firm, John Lenn and Co., by no means one of the largest, was sending out up to 50,000 circulars at a time in the mid-1880s. ${ }^{56}$

Print could be exploited in other ways. If newspapers and circulars were relatively ephemeral methods of communication, then brokers also produced longer-lasting publications. Wanting to reach people who knew nothing about investment, many of them produced introductory guides and handbooks giving the history of the Stock Exchange, explaining the jargon of the markets, and outlining investment strategies. By the 1880s, most of the larger outside firms had at least one such guide, and some were more ambitious, George Gregory and Co. offering the public a library of no less than 24 publications by $1896 .{ }^{57}$ This period even saw occasional, though significant, sorties into fiction. Both John Shaw and George Gregory co-authored fiction with the Victorian hack novelist and barrister Bracebridge Hemyng. In 1885, Hemyng published The Stockbroker's Wife, a collection of tales of speculation "edited" by Shaw, while in 1894 he followed up with a novel, A Stock Exchange Romance, "edited" by Gregory. These productions enabled brokers to get their message across to readers who might not look at the investment ads in the newspaper, but who would happily devour a sensational tale, particularly one in which "every commandment is broken." 58

Crucially, the visibility this advertising onslaught conferred on outsiders led many novice investors to assume that they were actually members of the London Stock Exchange. ${ }^{59}$ This prompted the Stock Exchange's own foray into print. From 1879 it began publishing an annual list of its members in The Times, though proposals to turn this into a weekly list were stymied by qualms about the cost. ${ }^{60}$ But in 1885 , with the outside broker threat intensifying, the Stock Exchange paradoxically began placing a regular press advertisement informing the 
public that its members did not advertise, and that investors could obtain a list of members on application. ${ }^{61}$ This was quite a financial commitment, costing around $£ 1,000$ annually, and initially, it seemed to have an effect. The Secretary to the Committee for General Purposes reported in December 1886 that he was receiving an average of seven or eight letters daily as a result of the notice and had issued some 1,800 lists to inquirers. ${ }^{62}$ It seemed that the Stock Exchange had successfully turned the outsiders' greatest weapon - advertising - against them. But this was wishful thinking. A list, without any elaboration as to why one name rather than another should be selected, was of limited use to new investors. The Secretary admitted that many enquirers asked him to recommend a broker, which he was not permitted to do. Moreover, the Stock Exchange's restrained notice had to compete with the altogether more interesting fare provided by the outside brokers. Such a half-hearted embrace of advertising was unlikely to "attract the attention of investors and speculators," claimed critics. ${ }^{63}$ Even some within the Stock Exchange recognized that such "a stereotyped advertisement ... would soon cease to attract any notice." ${ }^{\prime 64}$ Only one side in this contest was using print to its full potential.

\section{Sanitizing Speculation}

The outsiders' exploitation of print conferred other advantages besides visibility. It allowed them to influence attitudes and shape debates. Historians have long recognized that the expansion of consumer society from the late Victorian period entailed significant cultural change alongside economic and institutional innovation. In particular, manufacturers and retailers who were developing markets for consumer goods needed to overcome entrenched cultural prejudices against credit. "Extravagant spending on luxuries," Peter Scott explains, was "seen as the antithesis of the self-reliance and prudence which underpinned 'respectable' 
Victorian families." Marketing campaigns therefore focused on assuaging consumers' fears about "the perceived risks of buying on credit." ${ }^{65}$ Similarly, the biggest obstacle to the business of the outside brokers was deep-seated resistance to speculation, which informed much writing about the stock market. By the later nineteenth century, blanket condemnations of speculation on moral grounds had given way to a more class-inflected approach which tolerated the activity, but only amongst the wealthy. ${ }^{66}$ Financial authorities typically adopted a paternalistic tone when addressing smaller investors. Francis Playford, one of the very few member brokers to pen an advice manual, told his "inexperienced" readers to steer clear of time bargains and stick to the Funds as "the safest possible investment." $" 67$ The financial journalist A. J. Wilson explained that those of substantial means could legitimately indulge in the "perilous luxury" of speculation because they could afford to lose, but the majority had to satisfy themselves with "carefully selected stocks of the best class," even if this meant receiving modest returns. ${ }^{68}$ The message that "high interest means bad security" was endlessly drummed into such readers, who were also periodically reminded of Benjamin Disraeli's paean to the "sweet simplicity of the Three Per Cents." ${ }^{69}$ There was thus a world of difference, rhetorically at least, between risky speculation and steady investment.

Outside brokers sought to disrupt these distinctions. Though a minority adopted a sensationalist sales pitch (as in Reeves \& Co.'s 1875 publication How Fortunes are Made on the Stock Exchange), the majority sought to invest speculation with the respectable and prudential connotations of investment. To begin with, they recommended speculative approaches whilst distancing themselves from the word and its toxic connotations. So, in an 1869 book called Double Your Income, the Omnium Investment Agency reassured readers that their object was not "to lead or advise them to speculate in any way whatever," but to help them "to improve their position by the practice of sure and safe principles, without in any way trusting their property to the chances of speculation." ${ }^{" 70}$ In time, however, outside 
brokers sought to sanitize speculation. Their promotional materials increasingly conflated it with investment, as with Gutteridge's Speculation and Investment in Stocks and Shares (1882), Percy Campbell's True Principles of Steady Successful Speculation and Investment (1885), and Duncan on Investment and Speculation in Stocks and Shares (1895). Investment and speculation, according to the author of the last of these, were "twin sisters, and so nearly alike that it is almost impossible to discriminate between them," since both activities aimed to maximize returns and minimize risks. The logical result was a policy of "speculative investments." 71

What helped this message to resonate was the sustained decline in yields on government securities that made ultra-cautious approaches to the market less attractive. The Crimean War had seen the last major issues of Consols; after this, Gladstonian finance and redemption had begun to shrink the national debt. The reduction of yield was formalized in 1888 when Chancellor of the Exchequer George Goschen created conversion stock bearing $23 / 4$ per cent interest till 1903 , falling to $2 \frac{1}{2} 2$ per cent thereafter. ${ }^{72}$ Outside brokers warned the public that what were once considered risk-free investments in fact carried their own dangers, of sacrificing the income that could be obtained by a more active approach to the market. The false belief that small interest ensured safety and large interest spelled danger was a fallacy "that keeps money idle and moneyed people poorer than they need be."73

Though branded as little short of gambling by its critics, speculation on the cover system was not presented in this way by outside brokers. Their adverts stressed the prudential element - it was “STOCK EXCHANGE SPECULATION ON LIMITED LIABILITY," and "STOCK-EXCHANGE DEALING MADE SAFE."74 They could do this because although the public's potential profits were limitless, the losses were defined and limited - even if the stock fell twenty per cent, they would only lose their one per cent cover. Brokers thus recommended this system "with a view of protecting our clients" from the "violent 
fluctuations" which could occur in times of panic. ${ }^{75}$ The seeming transparency of the liabilities and charges were particularly significant at a time when the opacity of inside brokers' commission rates was a constant cause of complaint. ${ }^{76}$ As cover was deposited upfront, it was also a method of dealing which protected the broker against clients who might otherwise amass large debts they were unable to pay. This can therefore be seen as the financial equivalent of the ready-money, fixed-price system that was transforming the shopping experience. ${ }^{77}$ One of the chief objections to the idea of people of modest means speculating - that they could not withstand the risks they ran - was therefore undercut. Anyone who could find the $£ 5$ or $£ 10$ usually advertised as the minimum level of cover could become a speculator. The outside brokers therefore claimed that they were democratizing finance - opportunities for realizing large returns "were formerly limited to persons in direct communication with the City, and involved the handling of large sums of money." But now a wider public could participate, "at any distance, and without interruption to their usual pursuits, and ... the actual money handled need be but little." ${ }^{, 78}$ Even their staunchest critics admitted that the cover system placed speculation "practically within the reach of all."79 Just as canny retailers were turning shopping for pleasure into a luxury that could be experienced by a mass middle-class audience, so speculation was presented as a form of leisure which could be enjoyed in comfort and with one's respectability intact. The larger outside brokers ploughed substantial resources in their offices, expanding them piecemeal as neighboring premises became available, mirroring the process by which draper's shops were evolving into department stores. ${ }^{80}$ In 1884 , the Civil Service Gazette described John Shaw's offices as "comfortably, even luxuriously furnished, and clients, or intending clients, would find them a most comfortable lounge or resting-place." ${ }^{81}$ There, one had free access to "telephones, financial journals, record books, and papers." 82 George Gregory went one further: his Hints to Speculators and Investors contained fold-out illustrations of his offices in 
Tokenhouse Buildings, by the Bank of England, depicting respectable middle-class customers enjoying what looked more like club rooms, reading newspapers, writing letters, making phone calls, and engaging in polite conversation. These illustrations, which gave a "birdseye view" of the offices, also reinforced the transparency of Gregory's business. Readers were encouraged to survey the entire space before paying a visit, to reassure themselves that they could visit with safety, and quite possibly profit.

Moreover, whereas inside brokers were not permitted to branch, outside brokers did. Both Shaw and Gregory opened branches in popular retail and leisure spots in the West End, such as Westbourne Grove in Bayswater, close to Whiteley's department store, New Oxford Street, opposite Mudie's Library, and on Piccadilly, opposite the recently-constructed Pavilion Theatre, an upmarket West End music hall. ${ }^{83}$ Outsiders were thus responsible for bringing speculation out of its confines in the alleyways of the City and into the safer and better-known spaces of the fashionable West End. These West End exchanges were patronized because they made speculation both convenient and respectable - it could easily be integrated into one's daily routines without loss of face. As journalist, author, and denizen of clubland Joseph Hatton, explained,

You can go in and speculate and gamble, at a rate never dreamt of by those wild, tearing, duelling gamesters of Walpole's time: you can do it in cold blood in your morning coat, then take a ride in the park, lunch calmly at your club, go home unruffled to dinner, and escort your wife to the Opera in the evening, or to a meeting at Exeter Hall with the mild air of a bishop. ${ }^{84}$

Customers could thus move seamlessly between these different leisure spaces - department stores, libraries, clubrooms, and outside brokerages - speculation joining the ranks of at least semi-respectable pleasures available to the late-Victorian middle classes. Outside brokerages also multiplied in towns and cities across the country. The large London firms opened 
provincial branches: by the end of 1887, Shaw was operating in Manchester and Brighton, while by 1891 , Gregory had outlets in Brighton, Hastings, Folkestone, Leeds, and Hull. ${ }^{85}$ But here they faced stiff competition from local offices offering similar services. As early as 1885, for example, Manchester residents could make "unlimited profits with limited risks" with Max Browne \& Co. on Market Street, or try their luck with T. P. Edwards on Bank Street, who transacted "Stock Exchange Business with Limited Liability." 86

Though some accounts gendered speculators as male, outside brokerages had many female clients, capitalizing on women's longstanding involvement in the financial markets. ${ }^{87}$ One commentator hinted at a taboo about women entering such spaces, suggesting that "lady tapers wait about the city whilst their male friends operate for them," but it is clear that women also participated directly. ${ }^{88}$ One account described a "bold woman" who typically spent the day at her broker's, sitting "in the room where the tapes tick off the latest quotations hour after hour." Departing ostensibly for lunch, she in fact was on the hunt for information, often hurrying back "with a tip that may turn out particularly well." 89 Though men preponderated in the illustrations in Gregory's Hints to Speculators, several female figures can also be seen, underlining the idea that women could safely negotiate these spaces. By the early 1890s, the Yorkshire Evening Post observed disapprovingly that "the craze for gambling with the bucket-shop man is growing amongst women," with the number of cases in the courts involving women on the rise. ${ }^{90}$ Another editorial even claimed that it was "well known in the City that ladies form the bulk of the clientele of 'bucket shop' keepers." 91

What made speculation even easier is that it did not require constant attendance at the broker's office. It could be conducted by post, telegraph, or - increasingly - telephone, and tracked through price lists in the daily newspaper. These facilities made it easy for men and women to keep their speculations secret, whether from employers or family members, thus mitigating feelings of guilt or shame. As one author noted, people could now "speculate 
without anyone being the wiser." 92 This brought the stock market into the home, embedding it into the rituals of everyday life. "How many serious and revered fathers of families open their paper every morning with all the excitement of the baccarat player feverishly watching the turn of a card!" wondered the authors of one survey of the Edwardian West End. ${ }^{93}$ This domestication of speculation made it much easier and much more imaginable to play the markets.

\section{Winning Trust}

Nevertheless, outside brokers could only legitimize speculation if they could persuade people to trust them. To understand how brokers cultivated trust, we need to contextualize decisions to invest by looking more closely at the special characteristics of the media they used.

Discussing the clients of outside brokers, the Financial Times observed that

The majority of these people would flatly refuse to hand over cash to a casual stranger who accosted them in the street and made them flattering offers in return - they would, indeed, be inclined to hand him over to the police for trying to obtain money by false pretences - but to an exactly similar request made through a newspaper or the post they make a ready response, and probably feel pained if they are called fools for having done so. ${ }^{94}$

Why was this so? The Pall Mall Gazette suggested that it was a question of the relative novelty of print. "Mankind has had some thousands of years' experience of the use and abuse of the human voice." But "[p]ut a thing in print and a thousand men will believe it for one who would have believed it had it ever reached them through the ear." This was particularly true of investors, and the paper thought it was "a vain aspiration to hope that men may some day be as rational with their eyes as they are with their ears." 95 
Though identifying an important point, these commentators ultimately exaggerate the gullibility of bucket shop customers, missing the key difference between the two methods. Whereas the face-to-face approach demands an immediate response, the written appeal allows a choice to be made over a period of time. Alan Mackintosh has recently argued that this temporal aspect to decision-making was crucial to the success of the much-maligned patent medicine trade. He sees the two defining characteristics of such advertising as the communication of detailed information and constant reiteration. This enabled "a negotiating process" between vendor and customer "which might be lengthy. Consumers expected to see the same information several times," and could assimilate it at their own rate. This meant that "a medicine might seem familiar even before any of it had been taken."96 Outside brokers were operating in a very similar way, creating a sense of familiarity - and therefore safety through ubiquity in the press and other media. If readers were not immediately convinced by an advertisement, they could ponder the proposition over time, at their own pace, and be gradually persuaded. The effect was compounded by the sheer volume of outside broker advertising. Though in competition with one another, their advertisements fundamentally corroborated each other's claims, endlessly amplifying and embellishing them so that they hardened into received wisdom.

From familiarity it was a short step to intimacy, for print allowed brokers to simulate a personal appeal which helped them win trust in an impersonal market. Though some outside brokerages were incorporated as limited companies and adopted an institutional persona, many others were organized as partnerships, and foregrounded the personality of their proprietors. ${ }^{97}$ Their advertisements took advantage of the perceived aloofness of inside brokers by stressing their approachability and inclusivity, reassuring potential clients that "the same attention is given to the smallest operator as to the largest." 98 Whereas inside brokers were often wary of giving advice, it was different with outsiders: Shaw's clients could come 
and confer with "the intelligent and numerous staff who ... are thoroughly experienced and well able to advise and enlighten even the dullest of those interested in monetary matters." 99 Often written in the first person, their advertisements adopted a personable tone; after he refurbished and extended his head office, Shaw extended newspaper readers a personal invitation: "Should you be in the neighbourhood of Wardrobe-chambers, may I ask you to call and see the various improvements that have been recently made?" ${ }^{100}$ Like many other brokers, Shaw offered a discretionary service where clients would send money and he would "watch the market closely in order to choose the most favourable opportunity for operating on their behalf." 101 His advertisements tried to make "John Shaw" a shorthand for honesty, a brand that the public would recognize and trust - "a STRAIGHTFORWARD, HONOURABLE, and RESPONSIBLE MAN." 102

These techniques helped to entrench the idea of the outside broker as not simply a businessman but also a friend, adviser, and confidante. George Gregory placed advertisements every Christmas wishing season's greetings to "Clients and Friends." ${ }^{103}$ By 1894 this had evolved into an annual light-hearted poem or short story in which Gregory invariably featured, conveying tips and quips to his clientele. ${ }^{104}$ He even experimented with the free gifts which were a common device in the market for consumer goods. ${ }^{105}$ In 1894 he started distributing branded blotting pads, while two years later he grabbed more attention by sending a thousand walking canes to clients as a New Year's gift. ${ }^{106}$ Moreover, the investment guides and manuals which Gregory and his fellow brokers distributed gratis also acted as gifts underlining their giver's benevolence. His ads boasted that he had published "for the information and guidance of the investing public more literature than all the members of the Stock Exchange put together. ... Not being bound by the red tape of the Stock Exchange," he was "able to supply these works to the public free of charge." 107 Such strategies highlight the salience of ideas from the field of "emotional finance," most notably 
that trust in financial markets is not simply a matter of "rational" calculation but is built on stories "weaving together reason and emotion." 108 Having access to personalities like Shaw and Gregory as figures of trust helped clients to manage the anxieties generated by decisionmaking under conditions of uncertainty. ${ }^{109}$

The location of brokers' advertisements was critical to the project of persuasion. Existing scholarship tends to focus on the outsiders" production of "sham" newspapers which "mimicked ... mainstream financial publications" but lured readers to buy worthless securities. ${ }^{110}$ More significant, however, was their close relationship with the mainstream press, for if their messages were restricted to their own publications, they would have had limited wider resonance. As newspaper reading became a habit for growing numbers in the later nineteenth century, newspapers were imbricated in the fabric of readers' everyday lives, their serial nature enabling the building of trust over time. ${ }^{111}$ The relationship was not based simply on perceptions of reliability and credibility: newspapers were keen to construct "emotional communities" with their readers based on deeper affective bonds. ${ }^{112}$ Advertisements thus enjoyed a degree of transferred authority from the medium in which they appeared, a shortcut to trust. ${ }^{113}$

The most respectable of newspapers were happy to print the advertisements of the outsiders, and to give them privileged positions. London dailies like The Standard and the Daily News sometimes placed full-column ads for outside brokers directly alongside their City articles, while popular society magazines like Truth allowed notices for outsiders to appear at the foot of their financial pages. ${ }^{114}$ This method gave the advertising broker an implicit seal of approval. Though these papers may have contained editorial content critical of outside brokers - Truth was famed for its exposure of swindling bucket shops alongside other fraudsters - the fact that they also carried advertisements for outside brokers blunted the criticism. ${ }^{115}$ The warnings may even have helped advertising brokers, for the logical 
inference was that they applied to other brokers, not the ones who advertised in that journal. The idea that newspapers had a responsibility to police their advertising columns was a minority view. One of the objectives of the Provincial Newspaper Society, a trade organization established in 1836, was to collect and disseminate information about advertisers and advertising agents. ${ }^{116}$ But this was with the intention of protecting members from imposition, rather than the public. The Society's circular often contained warnings about particular brokers, warnings which members could pass on to their readers if they wished, but it was happy for its members to continue accepting advertisements from them, simply advising that they should insist on payment in advance. ${ }^{117}$

The authority of the newspaper was exploited even more directly with "puffs," or disguised advertisements, a ubiquitous facet of the nineteenth-century press. ${ }^{118}$ Papers, particularly provincial ones, frequently published copy written by businesses in their news columns without any indication of its origin, a trade arranged via reputable London advertising agencies. Outside brokers made great use of this service for it was doubly useful, not only for the puff itself, but also for the opportunity it gave to quote from the puff in advertisements, creating the appearance of a chorus of approval. ${ }^{119}$ Though some newspapers levied a premium of 25 per cent for leaving out the crucial word "advt," the costs were far from prohibitive, the Staffordshire Sentinel apparently charging just a shilling a line, while puffs in financial newspapers could be had for as little as $£ 2$ a time. ${ }^{120}$ Puffs also took other forms, such as recommendations to invest with a particular broker in the "Answers to Correspondents" column, or even celebrity interviews with recommended brokers. ${ }^{121}$

Moreover, even articles that were critical of outside brokers sometimes blurred rather than clarified moral distinctions between insiders and outsiders. For example, The Economist admitted that time bargains in the Stock Exchange were no different in principle from wagers in an outside brokerage. ${ }^{122}$ Moreover, it recognized that some of what went on in the House 
"cannot be termed straight," and that the "dodges" of "some of the less reputable members ... might almost make a respectable 'bucket shop' blush," such as unloading "rotten securities" onto their clients. ${ }^{123}$ Commentators frequently drew attention to the Stock Exchange's failure to reform itself and modernize its business practices, despite a Royal Commission report which had recommended reforms in $1878 .{ }^{124}$ The Saturday Review, for example, complained that the Stock Exchange enforced "obsolete" and "antiquated" rules, which added "extravagantly" to the costs borne by clients. ${ }^{125}$ This meant that it was quite possible to criticize bucket shops but still value the competition they offered as a "corrective for powerful but defective monopolist institutions." 126

Conflicting views could thus be found across the range of the newspaper press and within individual titles. The idea of a newspaper speaking with a coherent voice only gradually developed with the onset of the "new journalism" of the late nineteenth century. Recognizing Victorian newspapers as miscellanies of different, often contradictory, voices which the reader, rather than editor, was expected to interpret, is crucial to understanding the task facing investors. ${ }^{127}$ Wondering why "some people insisted on ignoring the advice appearing almost daily in the press, and continued to hand money to bucket-shop keepers" downplays the contradictions that characterized the market for information and advice, and the emotional dynamics underpinning investment. ${ }^{128}$

\section{Competition or Collaboration?}

Although relations between insiders and outsiders were often antagonistic, there were also intersections between the two markets. ${ }^{129}$ While it was notorious that the money used to speculate on the cover system was not actually invested in the stocks concerned and was merely used to gamble on prices, some of this money did make its way into the House, for in 
cases where an outside broker faced heavy liabilities on a particular stock, he could choose to "hedge" with an inside broker. ${ }^{130}$ When it came to the outsiders' investment business, there were also ways for insiders to benefit. Not all securities were traded on the London Stock Exchange, and because of their ability to advertise, outside brokers were better placed than insiders to negotiate securities for which there was not a ready market, making them a handy go-between when a client wanted to buy or sell such a stock. ${ }^{131}$ And when outsiders did investment business in shares that were quoted on the London Stock Exchange, the only way they could do this was with inside brokers on a commission-sharing basis, which effectively cast them in the role of touts for the insiders. At a time when growing numbers of member brokers stretched business very thinly, this extra source of income was particularly valued. ${ }^{132}$ As one commentator noted, outside business brought "grist to the mill of many an inside broker who would otherwise have none ... many of the inside brokers absolutely depend for their livelihood upon the business brought to them by the outside brokers."133 Another commentator also noted this growing interdependence, observing that "many firms, including some of reputed high standing, are not only willing, but eager" to secure this business. ${ }^{134}$

Though it is difficult to quantify the scale of their dealing with any confidence given the potential unreliability of their own numbers, the outsiders were clearly becoming a significant presence on the market. Despite 1893 being a "disastrous" year on the Stock Exchange, Gregory seemed unaffected, choosing this moment to enlarge his headquarters, which occupied 5,000 square feet by the end of the year. ${ }^{135}$ He was employing 100 clerks by this time, and boasted that " $[\mathrm{t}]$ he trade of a day frequently involves the handling of English and American Railway shares to the amount of half a million of pounds sterling." ${ }^{136} \mathrm{He}$ claimed to have 20,000 clients on his books, at a time when one of the largest inside firms had around 3,000, numbers which enabled him to declare himself "the biggest stockbroker on earth." ${ }^{137}$ It was not surprising that more than a few insiders wanted a piece of the action. In 
1893, the managing director of the Exchange Telegraph Company, Captain W. H. Davies, claimed that his outside subscribers did business with a total of 294 member brokers, dealing in $£ 53$ million of stock. One large outsider employed 20 members to do his business on the Stock Exchange, another had 15. While Davies had an interest in emphasizing the extent of cooperation in order to dissuade the London Stock Exchange from cutting off the outsiders, the numbers were based on a thorough inquiry by the agents of the company and verified with reference to the subscribers' books. ${ }^{138}$

Indeed, the relationship between the outside and inside markets became closer as some outsiders attempted to use their volume of business to move prices. In spring 1889 , for example, Gregory ran a sustained campaign to drive up the price of East London Railway Consolidated Stock, with his ads urging readers to "SQUEEZE THE BEARS," "CORNER THE BEARS," and "BUY EAST LONDON ORDINARY AND DEMAND DELIVERY."139 Market reports observed how the price of East Londons was rising, "owing to purchases effected by 'outside' brokers," though not to the extent that Gregory had hoped. ${ }^{140}$ By this time, it was not unusual for City columns to note the impact the activities of outsiders was having on the market, causing sudden upward movements or relapses. ${ }^{141}$ Rumours of the failure of any of the larger outside firms could temporarily depress prices. ${ }^{142}$

The outside market could seemingly withstand any scandal or failure, even involving the largest of its players. When Gregory died suddenly of pneumonia in 1897, it emerged that he had in fact been trading pseudonymously. ${ }^{143}$ His real name was Ashley Cronmire, which he had changed after his brother, Sidney, also a stockbroker, was criminally convicted of fraud in $1886 .{ }^{144}$ The case showed how easily old identities could be discarded and new ones crafted in print, and the fate of his business, which collapsed into insolvency after his death, underlined the precarity of the outsiders' business. ${ }^{145}$ Ironically, the insolvency was widely attributed to the success of his last tip, Great Easterns, which had risen far beyond his 
predictions, leaving him unable to pay his clients. ${ }^{146}$ After the failure "a great mistrust arose among the public" against outsiders, yet the business did not stay down for long, flourishing in the Edwardian period, when even critical journalists recognized the outside broker as constituting "a notable factor in the financial mechanism." 147

Outside brokers thus took a prominent place in the increasingly complex ecology of the City, which saw growing numbers of outside participants, including banks, investment trusts, and the London offices of foreign financial institutions. ${ }^{148}$ A revealing indicator of their influence was the number of rival agencies that started offering similar services and using similar methods, in the process blurring the boundaries between different types of financial actor. Banks began advertising their stock and share dealing services much more aggressively, and while they were not mistrusted to the same extent, this "touting for business" cast them in a comparable role to the outside brokers. ${ }^{149}$ Though the banks - like many outside brokers - brought their business to the House, their power was considered problematic by some. Provincial brokers were particularly concerned that banks allowed investors to bypass them when accessing the London market, one Liverpool broker arguing that "many Banks in the Provinces practically came within the definition of outside Brokers ... they were in fact Bucket Shops." ${ }^{" 150}$ Brokers on the London Stock Exchange also had reservations, one complaining in 1909 that many were "now practically the salaried clerks of the Banks, who were in reality acting as Stock Brokers." ${ }^{151}$ It was not only banks that were acting as alternative entry points to the stock market: even department stores were getting in on the act, with Whiteley's opening a stock and share dealing department for its customers before the start of the Great War. ${ }^{152}$

The fact that outside brokers sometimes established their own newspapers had begun to blur the boundaries between brokerage and journalism, and this process accelerated when the financial press started offering their readers stock and share dealing services. The 
Financial World's Stock and Share Agency, established in 1888 and dealing in "Mining, Brewery, Tramway, Omnibus, and Miscellaneous Shares," was an early example. ${ }^{153}$ While these were creating alternative markets to the London Stock Exchange, other services sought to funnel money into the official market. An example was The Critic, which established a stock and share agency for clients who did not feel confident dealing direct with a broker. For an annual fee of five guineas, clients could select the member broker they wished to do their business, and the agency would handle all transactions, including checking the broker's statements. ${ }^{154}$ Newspapers had long been a platform for trading, carrying advertisements of stocks and shares for sale or wanted. ${ }^{155}$ But the idea reached its apogee in 1912 with the opening of the Daily Mail Stock Exchange, a service to match buyers and sellers. The scheme prompted the ire of members, particularly as it was sold to the public using the methods of the bucket shop, the Daily Mail telling readers that it allowed them to bypass "the cumbrous organisation of the Stock Exchange, with its brokers' commissions and jobbers' profits."156 And, as with the bucket shops, some members thought that the Exchange Telegraph Company should be ordered to cut its supply of prices to the Northcliffe press. ${ }^{157}$ Thus, if the London Stock Exchange itself was slow to imitate the outside brokers' techniques for expanding the market, a variety of outside agencies were bringing these methods further into the mainstream. ${ }^{158}$

\section{Conclusion}

By highlighting the role of outside brokers in the development of the securities market, this article has sought to emphasize the importance of looking beyond official institutions and actors when studying the history of capitalism. As Kenneth Lipartito and Lisa Jacobson argue, understanding capitalism's complex ecosystem involves “interrogating the relationship 
between the manifest and the hidden, the mainstream and the marginal, and the licit and the illicit." "159 These other markets are not simply "appendages" to the "real" market, but can intersect with it, and influence how it operates and develops. It therefore makes sense, as Rob Aitken contends, to conceptualize these "fringe" markets "not as a space external to the conventional world of finance, but as a kind of border zone that is neither fully inside nor separate from that world." 160 Opening up these fringe markets for exploration helps us to rethink boundaries, relations, and practices in the history of capitalism.

Stepping outside the Stock Exchange provides a fresh, if unfamiliar, view of the development of investment and speculation in Britain, allowing us to subvert dominant narratives. Historians have contrasted the "[a]ggressive marketing campaigns" of the New York Stock Exchange in the early twentieth century with the lack of similar efforts in London "to promote shareholder democratization."161 Widening our focus to include the outsiders presents an alternative picture, allowing us to identify the aggressive marketing that was democratizing Britain's financial markets from the 1870s. Despite their enduring association with fraudulent practices, outside brokers were more than simply the London Stock Exchange's shadowy “others," whose poor reputation served to legitimize the official markets. In fact, their blanket advertising, prolific branching, and mass production of financial advice were instrumental in popularizing investment.

Recognizing this encourages us to explore hitherto neglected likenesses between consumer and financial markets in Britain. Rather than conceiving of these as distinct, we can reframe stocks and shares as another of the markets being transformed by innovative Victorian entrepreneurs seeking to reach untapped ranks of consumers by new methods. ${ }^{162}$ Labelled "quacks" by their opponents, outside brokers were indeed applying the methods of the patent medicine trade to financial products. ${ }^{163}$ When the outsiders made the process of speculation as simple as filling out a newspaper coupon - as Redway, Furness, and Co. had 
by 1909 - it is clear that they were disrupting boundaries between the stock market, consumer society, and the "new journalism" in ways that have been underappreciated. ${ }^{164}$ By sanitizing speculation and making it more accessible, they packaged "playing the market" as one of the new forms of commercialized leisure that could be enjoyed by late Victorians. Though there were many casualties, there were also beneficiaries, such as the elderly Nonconformist minister who, when interviewed by a reporter inside a bucket shop, "confessed that he had had a 'flutter' on the Stock Exchange every day for many years, and felt quite miserable without the mild excitement." 165 Such remarks bring out the emotional appeal of the stock market, which was able to generate a frisson of hazard in a society where lotteries were illegal, and other forms of gambling were becoming heavily restricted. Though many of their clients would never appear in a shareholder register, the outside brokers were responsible for drawing an unquantifiable number of Victorians into the stock market.

Bibliography of Works Cited

\section{Books}

Aitken, Rob. Fringe Finance: Crossing and Contesting the Borders of Global Capital, Abingdon: Routledge, 2015.

Ashton, John. The History of Gambling in England, London: Duckworth and Co., 1898.

Banner, Stuart. Speculation: A History of the Fine Line between Gambling and Investing, Oxford: Oxford University Press, 2017.

Bartlett, William, and Henry Chapman. A Handy-Book for Investors, London: Effingham Wilson, 1869. 
Clarke, Hyde, ed. The Railway Register, and Record of Public Enterprise, for Railways, Mines, Patents, Inventions, Vol. I, London: John Weale, 1845.

Crossick, Geoffrey, and Serge Jaumain, eds. Cathedrals of Consumption: The European Department Store, 1850-1939, Aldershot: Ashgate, 1998.

Crosthwaite, Paul, Peter Knight, Nicky Marsh, Helen Paul, and James Taylor. The History of Financial Advice: A Finder's Guide to the Collection at the Library of Mistakes, Edinburgh: Library of Mistakes, 2018.

De Goede, Marieke. Virtue, Fortune, and Faith: A Genealogy of Finance, Minneapolis, Minn.: University of Minnesota Press, 2005.

Dickson, P. G. M. The Financial Revolution in England: A Study in the Development of Public Credit, 1688-1756, London: Macmillan, 1967.

Duncan on Investment and Speculation in Stocks and Shares, London: Effingham Wilson, $1895,3^{\text {rd }}$ ed.

Gurney, Peter. The Making of Consumer Culture in Modern Britain, London: Bloomsbury, 2017.

Hatton, Joseph. Club-Land, London and Provincial, London: J. S. Virtue \& Co., 1890.

Hay, E. Double Your Income: Or, Resources of the Money Market, London: Omnium Investment Agency, 1869.

Henry, Nancy. Women, Literature and Finance in Victorian Britain: Cultures of Investment, Cham, Switzerland: Palgrave Macmillan, 2018.

Hewitt, Martin. The Dawn of the Cheap Press in Victorian Britain: The End of the "Taxes on Knowledge,” 1849-1869, London: Bloomsbury, 2013.

Hobbs, Andrew. A Fleet Street in Every Town: The Provincial Press in England, 1855-1900, Cambridge: Open Book Publishers, 2018. 
Hollow, Matthew. Rogue Banking: A History of Financial Fraud in Interwar Britain, London: Palgrave Macmillan, 2014.

Knight, Peter. Reading the Market: Genres of Financial Capitalism in Gilded Age America, Baltimore: Johns Hopkins University Press, 2016.

Kynaston, David. The City of London, Volume I: A World of its Own, 1815-1890, London: Pimlico, 1995.

Kynaston, David. The City of London, Volume II: Golden Years, 1890-1914, London: Pimlico, 1996.

Lewis, Brian. "So Clean”: Lord Leverhulme, Soap and Civilisation, Manchester: Manchester University Press, 2008.

Lipartito, Kenneth, and Lisa Jacobson, eds. Capitalism's Hidden Worlds, Philadelphia: University of Pennsylvania Press, 2020.

Long, Paul. How to Deal in Stocks and Shares, London: Long's Publications, 1926.

Mackintosh, Alan. The Patent Medicines Industry in Georgian England: Constructing the Market by the Potency of Print, Basingstoke: Palgrave Macmillan, 2018.

Magee, Gary Bryan. Productivity and Performance in the Paper Industry: Labour, Capital, and Technology in Britain and America, 1860-1914, Cambridge: Cambridge University Press, 1997.

Martin, James. The Broker's Correspondent; Being a Letter Writer for Stock Exchange Business, London: Effingham Wilson, 1893.

Michie, Ranald. The London Stock Exchange: A History, Oxford: Oxford University Press, 2001.

Morgan, E. Victor, and W. A. Thomas. The Stock Exchange: Its History and Functions, London: Elek Books, 1969. 
Mortimer, Thomas. Every Man His Own Broker: Or, A Guide to Exchange-Alley, London: S. Hooper, $1762,5^{\text {th }}$ ed.

Munting, Roger. An Economic and Social History of Gambling in Britain and the USA, Manchester: Manchester University Press, 1996.

Murphy, Anne. The Origins of English Financial Markets: Investment and Speculation before the South Sea Bubble, Cambridge: Cambridge University Press, 2009.

Nevett, T. R. Advertising in Britain: A History, London: Heinemann, 1982.

Nevill, Ralph, and Charles Edward Jerningham. Piccadilly to Pall Mall: Manners, Morals, and Man, London: Duckworth and Co., 1908.

Ott, Julia C. When Wall Street Met Main Street: The Quest for an Investors' Democracy, Cambridge, Mass.: Harvard University Press, 2011.

Pixley, Jocelyn. Emotions in Finance: Distrust and Uncertainty in Global Markets, Cambridge: Cambridge University Press, 2004.

Playford, Francis. Practical Hints for Investing Money: With an Explanation of the Mode of Transacting Business on the Stock Exchange, London: Smith, Elder, \& Co., 1855.

The Post Office: An Historical Summary, London: HMSO, 1911.

Pounds Sterling: How to Make Money and Use It, London: Central Stock Exchange, 1894.

Preda, Alex. Framing Finance: The Boundaries of Markets and Modern Capitalism, Chicago: Chicago University Press, 2009.

Price, Leah. How to Do Things with Books in Victorian Britain, Princeton: Princeton University Press, 2013.

Rappaport, Erika Diane. Shopping For Pleasure: Women in the Making of London's West End, Princeton: Princeton University Press, 2001.

Robb, George. White-Collar Crime in Modern England: Financial Fraud and Business Morality, 1845-1929, Cambridge: Cambridge University Press, 1992. 
Roberts, Richard. Saving the City: The Great Financial Crisis of 1914, Oxford: Oxford University Press, 2013.

Scott, J. M. Extel 100: The Centenary History of the Exchange Telegraph Company, London: Ernest Benn, 1972.

Scott, Peter. The Market Makers: Creating Mass Markets for Consumer Durables in InterWar Britain, Oxford: Oxford University Press, 2017.

Smith, A. D. The Development of Rates of Postage: An Historical and Analytical Study, London: George Allen and Unwin, 1917.

Steinbach, Susie L. Understanding the Victorians: Politics, Culture and Society in Nineteenth-Century Britain, London: Routledge, 2017.

Stern, Julian. An Experiment in Respectability, London: Downey \& Co., 1895.

The Stock Exchange Vade Mecum: A Key to Safe Speculations, London: Robinson \& Co., 1877.

Stowe, Harriet Beecher. We and Our Neighbours: Or, the Records of an Unfashionable Street, New York: J. B. Ford \& Company, 1875.

Swinson, Chris. Regulation of the London Stock Exchange: Share Trading, Fraud and Reform 1914-1945, Abingdon: Routledge, 2018.

Taylor, James. Creating Capitalism: Joint-Stock Enterprise in British Politics and Culture, 1800-1870, Woodbridge: Boydell, 2006.

Thomas, W. A. The Provincial Stock Exchanges, London: Frank Cass, 1973.

Tuckett, David. Minding the Markets: An Emotional Finance View of Financial Instability, Houndmills, Basingstoke: Palgrave Macmillan, 2011.

Warren, Henry. The Customer's Guide to Banking, London: Grant Richards, 1904.

Whitlock, Tammy C. Crime, Gender and Consumer Culture in Nineteenth-Century England, Aldershot: Ashgate, 2005. 
Wilson, A. J. Practical Hints to Small Investors, London: Longmans, Green, and Co., 1893.

The Wordsworth Dictionary of Phrase and Fable, Ware, Herts: Wordsworth, 2001.

\section{Articles and Chapters}

Acheson, Graeme G., and John D. Turner. "The Impact of Limited Liability on Ownership and Control: Irish Banking, 1877-1914," Economic History Review 59, no. 2 (2006): 32046.

Acheson, Graeme G., Gareth Campbell, and John D. Turner. "Who Financed the Expansion of the Equity Market? Shareholder Clienteles in Victorian Britain,” Business History 59, no. 4 (2017): 607-37.

Barchas, Janine. "Sense, Sensibility, and Soap: An Unexpected Case Study in Digital Resources for Book History,” Book History 16 (2013): 185-214.

Burt, Roger. “The London Mining Exchange 1850-1900,” Business History 14, no. 2 (1972): 124-43.

Campbell, W. Gordon. "Stock Exchange," in Encyclopaedia of Accounting, ed. George Lisle, Edinburgh: William Green and Sons, 1904, vol. vi, 129-42.

Church, Roy. "Advertising Consumer Goods in Nineteenth-Century Britain: Reinterpretations," Economic History Review 53, no. 4 (2000): 621-45.

Coase, R. H. "The British Post Office and the Messenger Companies," Journal of Law \& Economics 4 (1961): 12-65.

Corley, T. A. B. "Competition and the Growth of Advertising in the U.S. and Britain, 18001914,” Business and Economic History 17 (1988): 155-67.

Cottrell, P. L. "Domestic Finance, 1860-1914," in The Cambridge Economic History of Modern Britain. Volume II: Economic Maturity, 1860-1939, eds. Roderick Floud and Paul Johnson, Cambridge: Cambridge University Press, 2004, 253-79. 
Crone, Rosalind. "Query: Victorian Reading," in Reading and the Victorians, eds. Matthew Bradley and Juliet John, Farnham: Ashgate, 2015, 111-26.

Freeman, Mark, Robin Pearson, and James Taylor. “'A Doe in the City’: Women Shareholders in Eighteenth- and Early Nineteenth-Century Britain," Accounting, Business \& Financial History 16, no. 2 (2006): 265-91.

Hochfelder, David. “'Where the Common People Could Speculate': The Ticker, Bucket Shops, and the Origins of Popular Participation in Financial Markets, 1880-1920," Journal of American History 93, no. 2 (2006): 335-58.

Hollow, Matthew. “A Nation of Investors or a Procession of Fools? Reevaluating the Behavior of Britain's Shareholding Population through the Prism of the Interwar Sharepushing Crime Wave," Enterprise \& Society 20, no. 1 (2019): 132-58.

Itzkowitz, David C. "Fair Enterprise or Extravagant Speculation: Investment, Speculation, and Gambling in Victorian England," Victorian Studies 45, no. 1 (2002): 121-47.

Maltby, Josephine, and Janette Rutterford. “'She Possessed Her Own Fortune:' Women Investors from the Late Nineteenth Century to the Early Twentieth Century," Business History 48, no. 2 (2006): 220-53.

Maltby, Josephine, Janette Rutterford, David R. Green, Steven Ainscough, and Carien van Mourik. "The Evidence for 'Democratization' of Share Ownership in Great Britain in the Early Twentieth Century," in Men, Women, and Money: Perspectives on Gender, Wealth, and Investment, 1850-1930, eds. David R. Green, Alastair Owens, Josephine Maltby, and Janette Rutterford, Oxford: Oxford University Press, 2011, 184-206.

Matheson, Donald. "The Birth of News Discourse: Changes in News Language in British Newspapers, 1880-1930," Media, Culture \& Society 22, no. 5 (2000): 557-73.

Michie, Ranald C. "Gamblers, Fools, Victims, or Wizards? The British Investor in the Public Mind, 1850-1930," in Men, Women, and Money: Perspectives on Gender, Wealth, and 
Investment, 1850-1930, eds. David R. Green, Alastair Owens, Josephine Maltby, and Janette Rutterford, Oxford: Oxford University Press, 2011, 156-83.

Nevett, Terence. "Thomas Barratt and the Development of British Advertising," International Journal of Advertising 7, no. 3 (1988): 267-76.

Nevett, Terry. "Advertising and Editorial Integrity in the Nineteenth Century," in The Press in English Society from the Seventeenth to Nineteenth Centuries, eds. Michael Harris and Alan Lee, Rutherford, NJ.: Fairleigh Dickinson University Press, 1986, 149-67.

Ott, Julia Cathleen. "When Wall Street Met Main Street: The Quest for an Investors' Democracy and the Emergence of the Retail Investor in the United States, 1890-1930," Enterprise \& Society 9, no. 4 (2008): 619-30.

Porter, Dilwyn. “"A Trusted Guide of the Investing Public': Harry Marks and the Financial News, 1884-1916," Business History 28, no. 1 (1986): 1-17.

Porter, Dilwyn. "'Speciousness is the Bucketeer's Watchword and Outrageous Effrontery his Capital': Financial Bucket Shops in the City of London, c. 1880-1939," in Cultures of Selling: Perspectives on Consumption and Society since 1700, eds. John Benson and Laura Ugolini, Aldershot: Ashgate, 2006, 103-25.

Preda, Alex. "The Rise of the Popular Investor: Financial Knowledge and Investing in England and France, 1840-1880," Sociological Quarterly 42, no. 2 (2001): 205-32. Roddy, Sarah, Julie-Marie Strange, and Bertrand Taithe. "The Charity-Mongers of Modern Babylon: Bureaucracy, Scandal, and the Transformation of the Philanthropic Marketplace, c. 1870-1912," Journal of British Studies 54, no. 1 (2015): 118-37.

Rosenberg, Anat. "Amongst the Most Desirable Reading': Advertising and the Fetters of the Newspaper Press in Britain, c. 1848-1914," Law and History Review 37, no. 3 (2019): $657-706$. 
Rutterford, Janette, and Josephine Maltby. “"The Nesting Instinct': Women and Investment Risk in Historical Context,” Accounting History 12, no. 3 (2007): 305-27.

Rutterford, Janette, and Josephine Maltby. "“The Widow, the Clergyman and the Reckless': Women Investors in England, 1830-1914," Feminist Economics 12, nos. 1-2 (2006): 11138.

Rutterford, Janette, David R. Green, Josephine Maltby, and Alastair Owens. "Who Comprised the Nation of Shareholders? Gender and Investment in Great Britain, c. 18701935," Economic History Review 64, no. 1 (2011): 157-87.

Rutterford, Janette, Dimitris P. Sotiropoulos, and Carry Van Lieshout. "Individual Investors and Local Bias in the UK, 1870-1935," Economic History Review 70, no. 4 (2017): 12911320.

Stringham, Edward. "The Emergence of the London Stock Exchange as a Self-Policing Club," Journal of Private Enterprise 17, no. 2 (2002): 1-19.

Sundin, Olof, and Helena Francke. "In Search of Credibility: Pupils' Information Practices in Learning Environments," Information Research 14, no. 4 (2009): 1-19.

Taffler, Richard. "Emotional Finance: Investment and the Unconscious," European Journal of Finance 24, nos. 7-8 (2018): 630-53.

Taylor, James. "Privacy, Publicity, and Reputation: How the Press Regulated the Market in Nineteenth-Century England,” Business History Review 87, no. 4 (2013): 679-701.

Thomas, Amy. “"Mart of the World': An Architectural and Geographical History of the London Stock Exchange," Journal of Architecture 17, no. 6 (2012): 1009-48.

Turner, John D. "Wider Share Ownership? Investors in English and Welsh Bank Shares in the Nineteenth Century,” Economic History Review 62, no. S1 (2009): 167-92.

Yamamoto, Koji. “Beyond Rational vs Irrational Bubbles: James Brydges the First Duke of Chandos during the South Sea Bubble," in Le Crisi Finanziarie: Gestione, Implicazioni 
Sociali e Conseguenze Nell'età Preindustriale: Selezione di Ricerche, Florence: Florence University Press, 2016, 327-57.

Newspapers and Magazines

Bath Chronicle

The Builder

Bulletin of the National Anti-Gambling League

Chambers's Journal

Civil Service Gazette

County Gentleman

The Critic

Daily Mail

Daily News

Derby Daily Telegraph

Devon and Exeter Gazette

Dundee Courier

Eastern Evening News

The Economist

Evening Telegraph

Financial Times

Fortnightly Review

Grand Magazine

Hastings \& St Leonards Observer

Hearth and Home

Jackson's Oxford Journal 
Liverpool Echo

Liverpool Mercury

Manchester Guardian

Manchester Weekly Times

Morning Post

National Observer

Newspaper Society Circular

New Monthly Magazine

The Observer

Pall Mall Gazette

Pump Court

Saturday Review

Shields Daily Gazette and Shipping Telegraph

St James's Gazette

The Standard

Stock Exchange

The Times

Tinsleys' Magazine

Truth

United Kingdom Stock and Sharebrokers' Directory

Weekly Irish Times

Women's Penny Paper

The World

World's Work

Yorkshire Evening Post 


\section{Unpublished Materials}

Davis, Lance, Larry Neal, and Eugene N. White. "The Development of the Rules and Regulations of the London Stock Exchange, 1801-1914," Vanderbilt University Seminar paper, 2004.

Heinemann, Kieran. “Popular Investment and Speculation in Britain, 1918-1987," PhD thesis, University of Cambridge, 2017.

Jefferys, J. B. "Trends in Business Organisation in Great Britain since 1856, with Special Reference to the Financial Structure of Companies, the Mechanism of Investment and the Relations between the Shareholder and the Company," PhD thesis, University of London, 1938.

Kynaston, David. “The London Stock Exchange, 1870-1914: An Institutional History,” PhD thesis, University of London, 1983.

Stoddart, Susanne Christina. "Pressing for Reform: The New Liberalism, the New Journalism and Emotion in Edwardian Liberal Newspapers," PhD thesis, University of London, 2014.

\section{Archives}

Guildhall Library

Liverpool Record Office

London Metropolitan Archives

Old Bailey Proceedings Online

Parliamentary Papers

\footnotetext{
${ }^{1}$ A point made in the US context in Ott, "When Wall Street Met Main Street," 626. See also Ott, When Wall Street Met Main Street.
} 
${ }^{2}$ Examples include Crossick and Jaumain, Cathedrals of Consumption; Rappaport, Shopping For Pleasure; Gurney, The Making of Consumer Culture.

${ }^{3}$ Michie, The London Stock Exchange, 203.

${ }^{4}$ Maltby et al, "The Evidence for 'Democratization"”.

${ }^{5}$ The requirements are outlined in Michie, The London Stock Exchange, 38-40.

${ }^{6}$ For references to outsiders, see Michie, The London Stock Exchange, 110, 204, 208;

Kynaston, The City of London, Volume I, 361-3; Kynaston, The City of London, Volume II, 60-2, 101-3; Morgan and Thomas, The Stock Exchange, 140-1, 166-7.

${ }^{7}$ Itzkowitz, "Fair Enterprise or Extravagant Speculation,” 130.

${ }^{8}$ Porter, "'Speciousness is the Bucketeer's Watchword."”

${ }^{9}$ Porter, "“Speciousness is the Bucketeer's Watchword,"” 104, 125, 106. The fraudulent activities of the outsiders are also discussed in Robb, White-Collar Crime, 87-91. The literature on outsiders in the US is more extensive: see, for example, Hochfelder, "WWhere the Common People Could Speculate"; Knight, Reading the Market, ch. 2; De Goede, Virtue, Fortune, and Faith, 68-81; Banner, Speculation, 92-104.

${ }^{10}$ Heinemann, "Popular Investment and Speculation," 6, 34.

${ }^{11}$ Hollow, “A Nation of Investors.” See also Hollow, Rogue Banking.

${ }^{12}$ Nevett, "Thomas Barratt"; Corley, "Competition and the Growth of Advertising"; Lewis, "So Clean"; Barchas, "Sense, Sensibility, and Soap."

${ }^{13}$ Porter, "'Speciousness is the Bucketeer's Watchword,"” 105; Hollow, "A Nation of Investors," 138.

${ }^{14}$ Digitization is useful for identifying relevant material, but this article also draws extensively on non-digitized titles, especially financial and specialist ones.

${ }^{15}$ A large collection of these manuals is housed at the Library of Mistakes, Edinburgh: Crosthwaite et al, History of Financial Advice. 
${ }^{16}$ Key works include Acheson and Turner, "The Impact of Limited Liability”; Turner, "Wider Share Ownership?"; Acheson, Campbell, and Turner, "Who Financed the Expansion"; Rutterford et al, "Who Comprised"; Rutterford, Sotiropoulos, and Van Lieshout, "Individual Investors."

${ }^{17}$ Dickson, The Financial Revolution in England, 502-3. It was estimated in 1761 that only one-third of brokers were sworn brokers: Morgan and Thomas, The Stock Exchange, 65; Mortimer, Every Man His Own Broker, 161.

${ }^{18}$ For an account, see Stringham, “The Emergence of the London Stock Exchange.”

${ }^{19}$ Thomas, The Provincial Stock Exchanges, 91-2, 198-201.

${ }^{20}$ Clarke, The Railway Register, 524-5. "Stags" continued to be spotted into the 1860s: "The Stock Exchange," Chambers's Journal, 10 June 1865, 366-8.

${ }^{21}$ Michie, The London Stock Exchange, 85.

${ }^{22}$ Burt, “The London Mining Exchange," 125-6, 129. See also "Something in the City," New Monthly Magazine 105 (December 1855): 498-500.

${ }^{23}$ Rutterford et al, "Who Comprised," 158-60.

${ }^{24}$ Hochfelder, "“Where the Common People Could Speculate,"” 338-40; Preda, Framing Finance, ch. 4; Scott, Extel 100, ch. 2. The negotiations to establish the service in London are documented in London Stock Exchange, Trustees and Managers Minutes, 1872-74, MS 19297/7, Guildhall Library.

${ }^{25}$ There were a further 27 West End subscribers. By contrast, there were 285 member subscribers: Exchange Telegraph Company, Table of Monthly Numbers of Members and Non-Members Subscribing to the London Stock Exchange Quotations, 1873-1898, MS 23013, London Metropolitan Archives.

${ }^{26} 186$ outside firms were listed in the United Kingdom Stock and Sharebrokers' Directory for 1885-6, London: W. J. Adams \& Sons, 1885, 56-61. Four years earlier, there had been 140: 
United Kingdom Stock and Sharebrokers' Directory for 1881-2, London: W. J. Adams \& Sons, $1881,92-5$.

27 Taylor, "Privacy, Publicity, and Reputation."

${ }^{28}$ Editorial, The Standard, 10 October 1887, 5. For other criticisms, see "Our London Letter," Shields Daily Gazette and Shipping Telegraph, 26 December 1884, 3; "The New Gambling," Manchester Guardian, 2 September 1885, 5; “The Stock Exchange and Outside Gambling Agencies," The Economist, 2 January 1886, 9.

29 “Gambling by the Million," Saturday Review, 9 March 1889, 278.

${ }^{30}$ These were places where "the worst and vilest of liquors" were mixed in buckets "and sold to wretched, crazed people who have fallen so low that they cannot get anything better." Stowe, We and Our Neighbours, 380. See also "Beyond the Atlantic," Weekly Irish Times, 3 June 1876, 5; "Whipping Women," Liverpool Echo, 2 October 1880, 4. For early examples of the term as applied to British brokerages, see The World, reprinted in Dundee Courier, 7 January 1885, 2; “Notes,” St James's Gazette, 13 August 1885, 5; Editorial, Eastern Evening News, 13 November 1885, 2.

31 “Our London Letter,” Derby Daily Telegraph, 7 October 1890, 2; “People, Places, and Things," Hearth and Home, 3 May 1894, 854; "Opportunities to be Neglected," Financial Times, 29 March 1901, 4.

32 “An Abstract of the Principal Clauses of an Act for the Regulation of Open Stock Exchanges and similar places," Bulletin of the National Anti-Gambling League 1 (November 1893): 75. For more on the League, see Munting, An Economic and Social History of Gambling, 25-7.

${ }^{33}$ For an early case, see Montgomery v. Harrison, The Standard, 12 November 1885, 6; “An Infant Stockbroker,” The Times, 12 November 1885, 7; “An Infant Stockbroker,” Devon and Exeter Gazette, 14 November 1885, 4. 
${ }^{34}$ The sequence of events is documented in London Stock Exchange, Minutes of SubCommittee Appointed to Confer with the Exchange Telegraph Company, 1886-94, MS 14608/1, Guildhall Library.

${ }^{35}$ Heinemann, "Popular Investment and Speculation," 54-7; Hollow "Nation of Investors," 152-3; Swinson, Regulation of the London Stock Exchange, ch. 11.

${ }^{36}$ The Times, 26 September 1898, 9.

${ }^{37}$ Yamamoto, "Beyond Rational vs Irrational Bubbles"; Heinemann, "Popular Investment and Speculation," 201-2.

${ }^{38}$ Michie, The London Stock Exchange, 109-10.

${ }^{39}$ Roland Belfort, “How Stockbrokers 'Beat Up' Business,” Grand Magazine, June 1907, 665-71, at 666; Hollow, "Nation of Investors," 148-9.

${ }^{40}$ Hobbs, A Fleet Street in Every Town, 108.

${ }^{41}$ Hewitt, The Dawn of the Cheap Press, 100-1.

${ }^{42}$ Hewitt, The Dawn of the Cheap Press, 111-12.

${ }^{43}$ Broker ads also sometimes rubbed shoulders with notices for other money-making propositions.

${ }^{44}$ The Times, 25 May 1860, 4.

${ }^{45}$ For examples of each, see The Times, 10 January 1883, 12; The Standard, 10 June 1885, 1;

Daily News, 7 December 1887, 7.

${ }^{46}$ Porter, "“A Trusted Guide of the Investing Public."”

${ }^{47}$ Porter, "“Speciousness is the Bucketeer's Watchword,"” 114-17.

${ }^{48}$ The Times, 30 April 1897, 15.

${ }^{49}$ Nevett, Advertising in Britain, 71.

${ }^{50}$ Crone, "Query: Victorian Reading,” 114. 
${ }^{51}$ For the early history of price lists, see Murphy, Origins of English Financial Markets, 97 106.

${ }^{52}$ Magee, Productivity and Performance, 20; Price, How to Do Things with Books, 140-8;

Smith, The Development of Rates of Postage, 220-3; The Post Office, 14; Coase, "The British Post Office."

53 The Post Office, 14.

${ }^{54}$ For a couple of examples, see London Stock Exchange, General Purposes Committee Minutes, MS 146000/44: 4 December 1878, 36; 14 July 1879, 376, Guildhall Library. In the latter case, the Committee described the broker's act as "reprehensible."

${ }^{55}$ By the early 1880s, over a dozen agencies offered these services, chief among them George Smith and Co. who charged just $£ 12 \mathrm{~s} 6 \mathrm{~d}$ per thousand addressed envelopes. "Circulars," The Builder, 15 December 1883, 778-80; Warren, The Customer's Guide to Banking, 365; Exchange Telegraph Company, Correspondence, Reports etc, relating to the London Stock Exchange, 1877-97, MS 23028: C. A. Streeten to Committee of the London Stock Exchange, 19 December 1884, London Metropolitan Archives.

56 “The Charge Against a Stockbroker," Morning Post, 17 June 1886, 6; Old Bailey Proceedings Online (www.oldbaileyonline.org, version 8.0), June 1886, trial of FREDERICK TAMBLYN (37) (t18860628-740).

${ }^{57}$ Liverpool Mercury, 12 November 1896, 8.

${ }^{58}$ Review by Whitehall Review, reprinted in The Times, 28 August 1885, 10.

59 “Sworn Brokers," Truth, 12 September 1878, 306-7.

${ }^{60}$ London Stock Exchange, General Purposes Committee Minutes, MS 14600/44: 9 January 1879, 91; 10 January 1879, 92, Guildhall Library; London Stock Exchange, Selected Appendices to the Minutes of the General Purposes Committee, MS 19515/3: Handwritten 
account of the history of the London Stock Exchange's advertisement, 1878-1902, Guildhall Library.

${ }^{61}$ The advert initially appeared in the London dailies, but was extended to a wider range of titles, both in London and nationally, by the end of the year. For examples of the advertisement, see The Standard, 10 August 1885, 4; Manchester Courier, 31 December 1885, 1; Jackson's Oxford Journal, 2 January 1886, 2.

${ }^{62}$ London Stock Exchange, Trustees and Managers Minutes, MS 19297/11: 1 December 1886, 207-8, Guildhall Library.

63 “Threadneedle Street,” County Gentleman, 31 October 1885, 1405.

${ }^{64}$ London Stock Exchange, Trustees and Managers Minutes, MS 19297/11: 10 December 1885, 114, Guildhall Library.

${ }^{65}$ Scott, The Market Makers, 3.

${ }^{66}$ Taylor, Creating Capitalism, 214.

${ }^{67}$ Playford, Practical Hints for Investing Money, iii-iv.

${ }^{68}$ Wilson, Practical Hints to Small Investors, 3-4.

${ }^{69}$ For an example of the former, see "In the City," The World, 10 March 1875, 5-6. For the origins of Disraeli's phrase, see Wordsworth Dictionary of Phrase and Fable, 1002.

${ }^{70}$ Hay, Double Your Income, 12-13.

${ }^{71}$ Duncan on Investment and Speculation, 5.

${ }^{72}$ Cottrell, "Domestic Finance," 257-8; Rutterford et al, "Who Comprised," 159-60.

${ }^{73}$ Duncan on Investment and Speculation, 2.

${ }^{74}$ The Standard, 18 January 1881, 7; The Times, 2 October 1884, 14.

${ }^{75}$ The Stock Exchange Vade Mecum, 6.

${ }^{76}$ Kynaston, “The London Stock Exchange,” 270-4. 
${ }^{77}$ Gurney notes that "ready-money transactions and fixed or ticketed prices ... took a good deal of the anxiety out of shopping for consumers of more slender means." Gurney, The Making of Consumer Culture, 23. See also Whitlock, Crime, Gender and Consumer Culture, $30-2$.

${ }^{78}$ Pounds Sterling, 4.

${ }^{79}$ Campbell, "Stock Exchange," 138.

${ }^{80}$ Shaw initially occupied 1-5 Wardrobe Chambers, but eventually filled 1-15: The Standard, 16 December 1887, 1; The Times, 9 January 1891, 11.

${ }^{81}$ Civil Service Gazette, 6 December 1884, 11.

${ }^{82}$ The Standard, 28 January 1885, 1.

${ }^{83}$ For the development of the shopping districts of the West End from the 1850s, see Rappaport, Shopping For Pleasure, 19-27; Steinbach, Understanding the Victorians, 112-14.

${ }^{84}$ Hatton, Club-Land, London and Provincial, 3-4.

${ }^{85}$ The Standard, 9 December 1887, 9; The Times, 18 August 1891, 10.

${ }^{86}$ Manchester Weekly Times, 1 August 1885, 1; Manchester Courier, 5 August 1885, 1.

${ }^{87}$ Freeman et al, "“A Doe in the City”; Maltby and Rutterford, "“She Possessed Her Own Fortune"”; Rutterford and Maltby, “The Widow, the Clergyman and the Reckless"”;

Rutterford and Maltby, “"The Nesting Instinct”"; Henry, Women, Literature and Finance.

${ }^{88}$ John Baker Hopkins, “Catch 'Em Alive, Oh!,” Tinsleys’ Magazine 40 (January 1887): 6372 , at 65 .

89 “The Man About Town,” County Gentleman, 11 September 1886, 1162.

${ }^{90}$ Editorial, Yorkshire Evening Post, 15 December 1893, 2.

${ }^{91}$ Editorial, Derby Daily Telegraph, 20 February 1894, 2. See also "Current News about Women,"Women's Penny Paper, 16 February 1889, 2.

${ }^{92}$ Ashton, The History of Gambling, 274. 
${ }^{93}$ Nevill and Jerningham, Piccadilly to Pall Mall, 85.

94 “A Bolt from a Bucket-Shop,” Financial Times, 5 January 1910, 4.

95 “The Black Sheep of the Press," Pall Mall Gazette, 21 January 1890, 1.

${ }^{96}$ Mackintosh, The Patent Medicines Industry, 207-8.

${ }^{97}$ Examples of the former include the Universal Stock Exchange, the London and County Stock and Share Agency, and the London and Paris Exchange.

${ }^{98}$ The Standard, 16 February 1885, 1. See also Bartlett and Chapman, A Handy-Book for Investors, 1-2.

${ }^{99}$ Civil Service Gazette, 6 December 1884, 11. For the reluctance of inside brokers to give advice, see Martin, The Broker's Correspondent, iv-v, 59-60; "In- and Out-Brokers," National Observer, 14 April 1894, 550.

100 The Times, 13 June 1888, 14.

${ }^{101}$ The Standard, 1 December 1884, 1.

102 The Standard, 18 May 1889, 1.

${ }^{103}$ The Standard, 27 December 1892, 1; Daily News, 1 January 1894, 1.

${ }^{104}$ The Times, 25 January 1894, 12; Morning Post, 25 December 1895, 1; The Standard, 1 January $1897,1$.

${ }^{105}$ Gurney, The Making of Consumer Culture, 68.

${ }^{106}$ Hastings \& St Leonards Observer, 7 April 1894, 7; The Observer, 8 April 1894, 2; Bath Chronicle, 10 May 1894, 6; Financial Times, 29 January 1896, 5; The Observer, 2 February $1896,2$.

${ }^{107}$ The Standard, 10 December 1892, 1. Scholars who have explored nineteenth-century advice literature have not emphasized the leading role taken by outsiders in writing and disseminating it: Preda, “The Rise of the Popular Investor"; Michie, "Gamblers, Fools, Victims, or Wizards?" 
108 Tuckett, Minding the Markets, 55.

${ }^{109}$ Pixley, Emotions in Finance, 27-8; Taffler, "Emotional Finance," 636-7.

${ }^{110}$ Hollow, “A Nation of Investors," 144, 147. Though Porter does note that the respectable London dailies carried outside broker adverts, his focus is "Bucket-shop journalism":

"'Speciousness is the Bucketeer's Watchword,"” 107.

${ }^{111}$ Hobbs, A Fleet Street in Every Town, 28, 351.

${ }^{112}$ Stoddart, "Pressing for Reform," ch. 2.

${ }^{113}$ For a discussion of the concept of transferred authority in a modern context, see Sundin and Francke, "In Search of Credibility."

${ }^{114}$ The Standard, 15 September 1892, 6; Daily News, 15 September 1892, 2; Truth, 23 June $1898,1581$.

${ }^{115}$ Weber, "Henry Labouchere"; Roddy, Strange, and Taithe, "The Charity-Mongers of Modern Babylon.”

${ }^{116}$ Rosenberg, “"Amongst the Most Desirable Reading,”” 676.

${ }^{117}$ Newspaper Society Circular, April 1887, 29; January 1889, 6; June 1891, 7.

118 Nevett, "Advertising and Editorial Integrity."

${ }^{119}$ For example, a single advertisement for John Shaw quoted puffs from the Railway Times, the Civil Service Gazette, the Investors' Guardian, and the Christian Union: The Standard, 10 June $1885,1$.

120 “The 'Bucket-Shop' Prosecutions,” Financial Times, 28 September 1897, 4; “"Bucket Shop' Trials,” Daily Mail, 5 November 1897, 3; Reg. v. Scott, The Times, 9 March 1894, 5.

${ }^{121}$ For examples, see Pump Court, 8 May 1889, 6; 13 February 1889, 208-9.

122 “Stock Exchange Control Over Outside Speculation,” The Economist, 27 September 1884, 1164-5. 
123 “The Business Morality of the Stock Exchange," The Economist, 1 November 1890, 137980.

${ }^{124}$ Royal Commission on Origin, Objects, and Constitution of London Stock Exchange, Parliamentary Papers, 1878, XIX. 263.

125 “The Stock Exchange and the Outside Brokers," Saturday Review, 14 April 1894, 390-1.

See also "In- and Out-Brokers," National Observer, 14 April 1894, 550.

126 “Brokers: Inside and Outside," Stock Exchange, 14 October 1893, 44-5.

${ }^{127}$ Matheson, "The Birth of News Discourse."

${ }^{128}$ Porter, “'Speciousness is the Bucketeer's Watchword,"” 125.

${ }^{129}$ This was facilitated by the fact that the London Stock Exchange's rules did not forbid its members from doing business with such outsiders: Davis et al, "The Development of the Rules and Regulations," 41, 51.

130 This is mentioned in a contemporary novel which gives a detailed picture of the business of the outside broker: Stern, An Experiment in Respectability, 226.

131 "Bucket-Shops and the Law," Financial Times, 13 January 1911, 5.

${ }^{132}$ One journalist claimed that there were "over 5300 members, but only business for about 500": Roland Belfort, “The Future of the Stock Exchange," World's Work, September 1907, $376-83$, at 380 .

133 “London Letter," Sheffield Daily Telegraph, 5 February 1889, 5. See also “The Money Market," The Standard, 21 July 1890, 8.

134 “The Stock Exchange and its Parasites," The Economist, 18 April 1885, 473. This observation was prompted by the bankruptcy of an inside broker after promoting and financing an unsuccessful outside brokerage, the London and Provincial Stock Exchange Company (Limited). 
${ }^{135}$ H. J. Jennings, “The Stock Exchange and the Public,” Gentleman's Magazine, 275 (October 1893): 420-6; “Messrs. George Gregory and Company,” Yorkshire Herald, 29 January $1894,7$.

136 “Messrs. George Gregory and Company,” Yorkshire Herald, 29 January 1894, 7.

${ }^{137}$ The Standard, 10 December 1892, 1. G. S. Herbert, an inside firm specialising in smaller investors, had 3,209 client accounts open between 1909 and 1913: Kynaston, "The London Stock Exchange," 117; The Times, 25 December 1894, 12.

${ }^{138}$ London Stock Exchange, Minutes of Sub-Committee Appointed to Confer with the Exchange Telegraph Company, MS 14608/1, 24 November 1893, 99-100, Guildhall Library. 139 The Standard, 30 March 1889, 1; The Standard, 2 April 1889, 1. 140 “Money-Market and City Intelligence," The Times, 1 May 1889, 12. 141 “Money Market,” The Standard, 2 April 1888, 6; “Money Market,” The Standard, 21 March 1889, 6; "Money Market,” The Standard, 26 April 1889, 6; “Money Market,” Manchester Courier, 12 September 1889, 4; "Money-Market and City Intelligence,” The Times, 18 December 1889, 11.

142 "Money-Market and City Intelligence," The Times, 25 October 1888, 11. 143 "Notes - Mainly Personal," Evening Telegraph, 19 April 1897, 2; "Law Report," The Times, 24 April 1897, 15.

${ }^{144}$ Reg. v. Cronmire, The Times, 8 April 1886, 12; Old Bailey Proceedings Online (www.oldbaileyonline.org, version 8.0), February 1886, trial of SIDNEY HERBERT CRONMIRE alias HERBERT HARRISON (20) (t18860208-282). 145 “The Late 'George Gregory,"” Yorkshire Evening Post, 23 April 1897, 3. 146 “The Tips of Outside Brokers," Pall Mall Gazette, 30 April 1897, 4; "The Cover System," Edinburgh Evening News, 4 May 1897, 4. 
147 “Law Report,” The Times, 24 December 1897, 8; Roland Belfort, “The Modern Outside Broker," World's Work, July 1907, 124-9, at 124.

${ }^{148}$ Michie, The London Stock Exchange, 97-8.

149 “A Bank Tout,” Truth, 29 September 1904, 789.

${ }^{150}$ Talbot Fair, Liverpool Stock Exchange, Committee Minute Books, 332 LSE/1/2/19, 28 February 1905, 24, Liverpool Record Office.

${ }^{151}$ Charles Bowerman, London Stock Exchange, General Purposes Committee: Minutes of Sub-Committees of a Non-Permanent Character, MS14609/3, 6 January 1909, 114, Guildhall Library.

${ }^{152}$ London Stock Exchange, General Purposes Committee Minutes, MS 146000/94: 13 July 1914, 142-4, Guildhall Library.

${ }^{153}$ Financial World, 4 August 1888, 3.

${ }^{154}$ The Critic, 7 January 1905, 22; 11 February 1905, 22-3.

155 Jefferys, "Trends in Business Organisation," 341.

156 “Chat on 'Change,” Daily Mail, 12 June 1912, 2; Roberts, Saving the City, 190-1.

${ }^{157}$ London Stock Exchange, Selected Appendices to the Minutes of the General Purposes Committee, MS19515/4, item 251, Guildhall Library.

158 The London Stock Exchange did not take on a public relations advisor until 1947:

Thomas, "“Mart of the World,"” 1032.

${ }^{159}$ Lipartito and Jacobson, Capitalism's Hidden Worlds, 12.

${ }^{160}$ Aitken, "Capital at its Fringes," 481. See also Aitken, Fringe Finance.

${ }^{161}$ Rutterford and Sotiropoulos, "The Rise of the Small Investor," 488.

${ }^{162}$ Church, "Advertising Consumer Goods." 
${ }^{163}$ For early and late applications of the term to outside brokers, see Henry May, "The London Stock Exchange," Fortnightly Review, 38 (October 1885): 566-80, at 578; Long, How to Deal in Stocks and Shares, 21.

${ }^{164}$ Financial Outlook, 8 May 1909, 4.

165 “A Nonconformist Minister in a 'Bucket Shop,” Pall Mall Gazette, 26 October 1889, 6. 